\title{
LINKAGE IN PEROMYSCUS
}

\author{
ROY ROBINSON \\ St Stephens Road Nursery, Ealing, London, W.13
}

Received I6.v. $6_{4}$

\section{INTRODUCTION}

Although the deermouse, Peromyscus maniculatus, has been known as a laboratory rodent for many decades, the animal has not been utilised as extensively as its intrinsic genetic qualities would warrant. However, if the deermouse is to have a more vital role in mammalian genetics, a review of the present situation would appear opportune. This paper presents the results of statistical combination of the published data on linkage studies with the known mutant genes of the species. Eighteen of these have been studied from the viewpoint of chromosome mapping, and information is available on 42 (28 per cent.) of the 153 possible different combinations. A critical collation would enable greater reliability to be attached to statements of supposedly independent inheritance.

\section{PROCEDURE}

The statistical technique employed is the system of maximum likelihood scoring first explicitly introduced by Fisher (1946) for this type of problem. That the technique is capable of yielding useful results has been shown by previous surveys on the mouse (Carter and Falconer, 1952), on the rabbit (Robinson, 1956) and on the rat (Robinson, 1960). The clear-cut simultaneous segregation of some genes was distorted by inviability or by impenetrance. Fortunately, it was possible for either inviability or impenetrance to be estimated as part of the analysis. Allowance for these disturbing factors was made only where the expected gene ratios were significantly distorted. Impenetrance was the more troublesome and was found to vary between samples for the same gene. After the effects of variable penetrance had been taken into account, the estimate of the recombination fraction was often a little different from that given in the original report. The methods described by Bailey (196I) were employed.

\section{THE DATA AND ANALYSIS}

The genes investigated for linkage are listed in table $\mathrm{I}$, together with brief remarks upon the nature of the difficulties which the genes may present to straightforward scoring. The independence data are arranged in table 2. This tabulation gives the estimated recombination fraction for the pooled data and a standard error based upon $p=0.5$; together with the score and amount of information. The column 
headed "phase balance" shows the percentage of the total amount of information derived from coupling segregation. That many of the pairs of genes are merely independent in the formal sense of not displaying an obvious linkage may be seen from the magnitude of the standard error. The entries for fig. I show the strength of linkage which could be compatible with the observed joint segregation at the 5 per cent. level of significance. This was approximated by multiplying the standard error of $p$ for 0.5 by 196 and subtracting from the observed crossover percentage.

\section{TABLE I}

Symbols of mutant genes of the deermouse; with remarks upon any disadvantage from the standpoint of linkage analysis

\begin{tabular}{|c|c|c|c|}
\hline Symbol & Designation & $\begin{array}{c}\text { Prime } \\
\text { characteristics }\end{array}$ & Remarks \\
\hline $\begin{array}{l}b \\
b g \\
c \\
d \\
e p \\
f \\
g \\
h r \\
i \\
n \\
\mathcal{N} b \\
p \\
S \\
s i \\
s p \\
v \\
W c \\
y\end{array}$ & $\begin{array}{l}\text { Brown-tip } \\
\text { Boggler } \\
\text { Albino } \\
\text { Dilute } \\
\text { Epilepsy } \\
\text { Flexed-tail } \\
\text { Grey-band } \\
\text { Hairless } \\
\text { Ivory } \\
\text { Nude } \\
\text { Wide-band } \\
\text { Pink-eye } \\
\text { White-face } \\
\text { Silver } \\
\text { Sperocytosis } \\
\text { Waltzer } \\
\text { White-cheek } \\
\text { Yellow }\end{array}$ & $\begin{array}{l}\text { Coat colour } \\
\text { Behaviour } \\
\text { Coat colour } \\
\text { Coat colour } \\
\text { Behaviour } \\
\text { Skeleton } \\
\text { Coat colour } \\
\text { Atrichosis } \\
\text { Coat colour } \\
\text { Atrichosis } \\
\text { Coat colour } \\
\text { Coat colour } \\
\text { Coat colour } \\
\text { Coat colour } \\
\text { Blood anomaly } \\
\text { Behaviour } \\
\text { Coat colour } \\
\text { Coat colour }\end{array}$ & $\begin{array}{l}\text { Epistasis } \\
\text { Impenetrance } \\
\text { Impenetrance } \\
\text { Impenetrance } \\
\text { Inviability } \\
\text { Inviability } \\
\text { Impenetrance }\end{array}$ \\
\hline
\end{tabular}

With 37 analysed combinations of genes, it might be expected that one or two could display significantly large chance deviations. In actual fact, one fortuitous deviation may have occurred. There is evidence that the data in toto is not as variable as might be expected. The $\chi^{2}$ of $22 \cdot 16$, with 37 degrees of freedom for the total data, would appear to be significantly smaller than the 5 per cent. admissible range about the mean $\chi^{2}$ for this number of degrees of freedom; as calculated by the $A_{3}$ approximation of Rao (1952). The implication would appear to be that any suspiciously large deviation has been followed up. It may be noted that a similar conclusion could be found in the published linkage studies of the rat (Robinson, 1960). It is probable that the sequential form of analysis proposed by McIntosh (1956a), should it be generally adopted, will accentuate this process.

The single large deviation which may have fortuitously surpassed the conventional level of statistical significance was observed by Feldman (1937) for the pair of genes $p$ and $S$. The $S$ gene has been 
tested for linkage with $c$ (which is linked with $p$ ) with completely negative results. However, this latter result cannot exclude loose linkage between $p$ and $S$, particularly should the genes $c$ and $S$ lie on

TABLE 2

Quasi-independent segregation

\begin{tabular}{|c|c|c|c|c|c|c|}
\hline Loci & $p$ & $s$ & Score & Information & $\begin{array}{l}\text { Phase } \\
\text { balance }\end{array}$ & References \\
\hline$b \cdot b g$ & 0.50 & O.II & 0 & $85 \cdot 33$ & 100 & Barto (I 955) \\
\hline$b-e p$ & 0.50 & 0.03 & -2 & 1364 & 26 & Barto (1956) \\
\hline$b-f$ & 0.50 & 0.04 & -0.89 & 540 & 0 & Huest is and Barto (1936) \\
\hline$b-g$ & 0.49 & 0.03 & -6 & $94^{8}$ & I OO & Blair (I 947) \\
\hline$b-h r$ & 0.50 & 0.03 & $-\mathrm{I} \cdot 78$ & $123^{\circ}$ & 0 & McIntosh ( $1956 a)$ \\
\hline$b-s i$ & 0.52 & 0.23 & 0.44 & $19 \cdot 56$ & 0 & Huestis and Barto (I 934) \\
\hline$b-v$ & 0.55 & 0.04 & $3^{74}$ & 704 & I 00 & McIntosh (I $956 a)$ \\
\hline$b-y$ & 0.52 & 0.03 & 22 & 1260 & o & McIntosh (1956a) \\
\hline$b g-h_{r}$ & 0.50 & $0 \cdot 1 \mathrm{I}$ & 0 & $85 \cdot 33$ & 0 & Barto (I955) \\
\hline$c-d$ & 0.52 & 0.04 & Io & 508 & o & Barto (1942) \\
\hline$c-e p$ & 0.50 & 0.03 & $3 \cdot 62$ & $104 \mathrm{I}$ & o & Barto (I 956$)$ \\
\hline$c-h r$ & 0.53 & 0.02 & 49 & 1982 & ? & $\begin{array}{c}\text { Sumner (1924), Feldman } \\
\text { (1 937), Clark (1938) }\end{array}$ \\
\hline$c-n$ & $0 \cdot 52$ & 0.03 & 21 & 944 & o & Barto (1942) \\
\hline$c-S$ & $0 \cdot 54$ & 0.05 & 14 & 396 & ? & Feldman (I 937 ) \\
\hline$c-v$ & $0.5 \mathrm{I}$ & 0.03 & II & 973 & 0 & Barto (I 942 ) \\
\hline$c-y$ & $0.4^{8}$ & 0.01 & -22 & 943 & $?$ & $\begin{array}{l}\text { Sumner (I } 922) \text {, Feldman } \\
\text { ( } 1937), \text { Clark (1938) }\end{array}$ \\
\hline$d-h r$ & 0.45 & 0.03 & -52 & 966 & 0 & Barto (I942) \\
\hline$d-i$ & $0.5 \mathrm{I}$ & 0.04 & 4 & 720 & 0 & Barto (I $94^{2}$ ) \\
\hline$d-v$ & 0.50 & 0.07 & -11 & 2401 & 83 & Barto (1956) \\
\hline$d-y$ & 0.53 & 0.06 & 8 & 252 & 0 & Clark (I938) \\
\hline$e p-s i$ & 0.47 & 0.06 & $-8 \cdot 28$ & 280 & 0 & Barto (1956) \\
\hline$f-s p$ & 0.49 & 0.05 & -4 & 400 & 100 & $\begin{array}{l}\text { Huestis, Anderson and } \\
\text { Motulsky }(\text { I } 956)\end{array}$ \\
\hline$f-v$ & 0.52 & 0.03 & 28 & I 399 & $4^{I}$ & Barto ( 1956$)$ \\
\hline$g-W_{c}$ & 0.47 & 0.03 & -26 & 812 & IOO & Blair (I 944) \\
\hline$h r-i$ & 0.52 & 0.03 & 23 & 1612 & 0 & Barto (1942) \\
\hline$h r-\mathcal{N} b$ & 0.52 & 0.03 & 16 & 888 & 100 & McIntosh (1956a) \\
\hline$h r-p$ & 0.51 & 0.03 & 6 & 860 & ? & Feldman ( I 937) \\
\hline$h r \cdot s$ & $0.5 \mathrm{I}$ & 0.03 & 6 & I 188 & $?$ & Feldman (1937) \\
\hline$h r-v$ & 0.52 & 0.04 & 12 & 792 & o & Barto (1956) \\
\hline$h r-y$ & 0.49 & 0.03 & -20 & I 560 & $?$ & $\begin{array}{l}\text { Feldman } \\
\left(\text { I } 93^{8}\right)\end{array}$ \\
\hline$i-v$ & 0.57 & 0.06 & I 6 & $24^{8}$ & 29 & Barto (1956) \\
\hline$i-y$ & 0.54 & 0.03 & 34 & $9^{16} 6$ & 0 & McIntosh (I 956a) \\
\hline$\tilde{N} b-y$ & 0.54 & 0.04 & 26 & 604 & o & McIntosh (I $956 a)$ \\
\hline$p-S$ & 0.44 & 0.03 & -60 & $93^{6}$ & $?$ & $\begin{array}{l}\text { Sumner and Collins } \\
\text { (I g22), Feldman (I 937) }\end{array}$ \\
\hline$p-y$ & 0.55 & 0.05 & $2 \mathrm{I}$ & 414 & $?$ & Feldman (1937) \\
\hline$S-y$ & $0.4^{8}$ & 0.03 & -24 & 1096 & ? & Feldman (I937) \\
\hline$v-y$ & 0.44 & 0.04 & $-3^{2}$ & 519 & 37 & Barto (1956) \\
\hline
\end{tabular}

Note.-Standard error $(s)$, score and amount of information are computed for the crossover percentage $(p)$ of $0.5 .^{\circ}$

opposite sides of $p$. It may also be noted that Feldman's material did not reveal linkage between $c$ and $p$, although the concomitant work of Clark (1938) did so, a very curious contradiction. Is it possible that an unknown factor caused unusually high recombination values in Feldman's material? If so, then it may be worthwhile to 
retest the two genes $c$ and $S$ for evidence of linkage. The piebald gene represented by $S$ would appear to be the dominant spotting gene designated as " white-face" by Feldman (1936).

A number of comments may be made on various aspects of the data. The breeding results shown by Sumner and Collins (1922) for the gene pair $c-y$ are the same as those given by Sumner (I922).

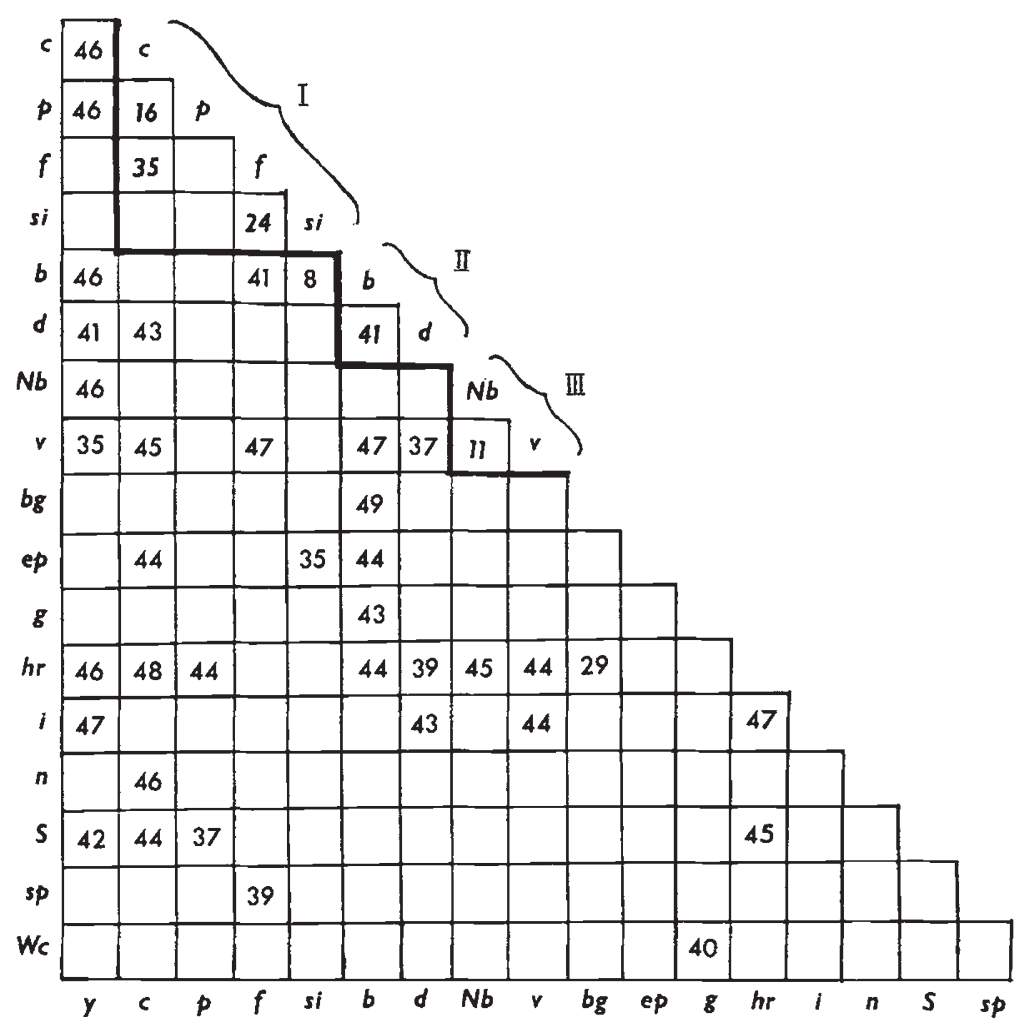

Fig. 1.-Summary of extent of linkage tests between genes of Peromyscus. Three linkage groups have been found and the recombination percentage shown is an average of the figures for each sex in table 3 . The percentages shown for the remaining genes are the closest linkage compatible with the published data.

Huetis and Barto (1934) have tabulated the results of a repulsion intercross for the gene pair $b-s i$, in which the phenotypic class frequencies are very different from expectation. The distortion is such that linkage is an improbable explanation and the estimate of $p$ in table 2 for these genes is derived from the two classes which are not distorted. McIntosh (1956a) is of the opinion that the precise identity of the mutant gene, designated by Clark (1938) as buff, is in doubt. McIntosh feels that buff may be identical to the wide-band gene. In view of this possible ambiguity, the data of Clark on the simultaneous segregation of buff with yellow and hairless has not been utilised. However, the data presented by Clark indicated that the buff gene 
was assorting very freely from either yellow or hairless. The allelic genes designated by Blair (1944, r 947) as buff versus grey (now greyband) are taken to represent a locus independent of buff or of wide-band.

Additional to those mutant alleles listed in table $\mathrm{r}$, a number have been recently reported which have not been tested for genetic linkage. Barto (1 954) has described a behaviour gene (spinner) which, however, suffers from the drawback of displaying impenetrance. A form of ventral white spotting (white-side) has been detailed by McIntosh $(1956 b)$. The mutant is inherited as a recessive to normal but is somewhat inviable prior to one month of age. A flavescent coat colour (orange-tan), which is said to differ phenotypically from yellow, has been described by Egoscue and Day (1958). The atrichosis (naked) announced by Egoscue (1962) would seem to differ phenotypically from hairless. However, the genetic distinctness of the last two mutants has yet to be directly proven from those other genes which they tend to resemble.

\section{ESTABLISHED LINKAGE GROUPS}

Five pairs of linked genes have so far been discovered. Table 3 gives details of the genes concerned and the amount of recombination

TABLE 3

Summary of established linkages

\begin{tabular}{|c|c|c|c|c|}
\hline $\begin{array}{l}\text { Linkage } \\
\text { group }\end{array}$ & Loci & Sex & $p$ & References \\
\hline \multirow[t]{3}{*}{ I } & $c-p$ & $\begin{array}{l}\text { ta } \\
\vdots \\
+\end{array}$ & $\begin{array}{l}0.135 \pm 0.056 \\
0.184 \pm 0.028\end{array}$ & Clark (1938) \\
\hline & $c-f$ & $\begin{array}{l}0 \\
0 \\
+\end{array}$ & $\begin{array}{l}0.300 \pm 0.055 \\
0.407 \pm 0.044\end{array}$ & Huestis and Lindstedt (1946) \\
\hline & $f-s i$ & $\begin{array}{l}0 \\
0 \\
+\end{array}$ & $\begin{array}{l}0.225 \pm 0.038 \\
0.255 \pm 0.019\end{array}$ & $\begin{array}{l}\text { Huestis and Piestrak (I } 932) \\
\text { Huestis and Lindstedt (1946) }\end{array}$ \\
\hline II & $b-d$ & $\begin{array}{l}0 \\
q \\
q\end{array}$ & $\begin{array}{l}0.397 \pm 0.035 \\
0.431 \pm 0.030\end{array}$ & McIntosh (1956a) \\
\hline III & $\mathcal{N} b-v$ & $\begin{array}{l}\text { ta } \\
\text { o }\end{array}$ & $\begin{array}{l}0.114 \pm 0.015 \\
0.106 \pm 0.014\end{array}$ & McIntosh (1956a) \\
\hline
\end{tabular}

observed, according to the sex of the doubly heterozygous parent. Not one of the sex differences in crossing-over is significant. The table also shows that the five genes of the first linkage group have not been tested in a sufficient number of combinations for any idea to be gained of their linear arrangement.

Linkage between the genes $c$ and $p$ was first observed by Sumner (1922) but he gave no firm data which could be utilised in this review. It is curious that Feldman (1937) failed to observe linkage between the genes $c$ and $p$. According to his figures, 82 crossovers were observed 
out of about i 83 animals, a crossover percentage of 44 and one which does not differ significantly from the value of 50 for independent assortment. However, Clark (1938), has presented definite evidence of linkage between the two genes. The results shown by Clark (1936) for these genes are presumably included among the more extensive tabulation given by Clark (1938). In addition to the backcross data of the table which have provided estimates of the incidence of crossingover for sexes, Huestis and Lindstedt (1946) have given details of an intercross segregation for the gene pair $c-f$. The crossover percentage for this segregation was $25^{\cdot} \cdot 93 \pm 9 \cdot 3^{2}$; a value lower than those of the table but not apparently inconsistently so.

The crossover values for the chromosome intercept $f$-si are based upon three homogeneous backcross samples. A fourth backcross sample, which was derived from male gametogenesis, gave the significantly lower rate of crossing-over of $9 \cdot 08 \pm 2 \cdot 93$ per cent. The reason for the low value for this particular sample is obscure (Huestis and Lindstedt, 1946). Aberrant as this value may be, a somewhat comparable estimate may be found in an intercross segregation for the same pair of genes (Huestis and Piestrak, 1952). The recombination percentage here was estimated to be $8 \cdot 22 \pm 2 \cdot 90$, after allowance had been made for impenetrance. It is possible that the difference in crossing-over may arise from an unexpected interaction between the genes. A number of preliminary reports appeared on the association of the genes $f$ and si (Huestis, 1940, 1942, I944, 1946), before the final data were presented. McIntosh (1956a) has noted that heterogeneity could be detected between the four sibships which constituted the data for female gametogenesis on the joint segregation of genes $b$ and $d$. The heterogeneity was due to the offspring of a single female, and stemmed from the fact that the amount of crossing-over was I $9 \cdot 40 \pm 4 \cdot 83$, a value which differed significantly from the percentage shown by the other sibships. McIntosh has rejected this sibship data as anomalous and this policy has been followed here. However, the situation may be noted for possible future reference.

\section{KARYOLOGICAL OBSERVATIONS}

The chromosome complements of some r 9 species and subspecies of Peromyscus have been determined to be $46+\mathrm{XY}$ (Cross, r93 1, r 938; Moree, 1946, I948; Harpst and Martin, I950; Matthey, I952, I953; Makino, I953a, b; and Tamsitt, I960). Forty-eight chromosomes have been consistently found for all investigated species of the genetically important maniculatus group, with the exception of hollisteri. Cross (1938) counted 52 chromosomes in spermatogonia cells of one individual of this subspecies but he admitted that this material may have been exceptional. He seemed to discount the possibility that chromosome fragmentation had occurred but Tamsitt (I960) considered that fragmentation was the most likely explanation. However, 
it would appear desirable that material of this subspecies should be critically re-examined before the figure of 52 chromosomes is unquestionably accepted.

Cross (1938), Moree (1946, 1948) and Tamsitt (196o) have concluded that the three species, truei, nasutus and comanche, of the truei group possesses 48 chromosomes. However, it may be noted that Makino $(1953 a, b)$, while agreeing that truei has 48 chromosomes, has stated that nasutus appeared to have 52. Finally, Cross (1938) gives the figure of 58 as the number of chromosomes for eremicus and fraterculus two determinations which have been queried by Tamsitt (1960).

However, pending re-investigation of the exceptional chromosome determinations, it would appear that the ultimate number of autosomal linkage groups will be 23 , with the possibility of another group which will display either total or partial sex-linkage. A conspicuous feature of the published linkage data is the absence of tests for partial sexlinkage. Though it could be argued that this type of linkage may be rare, the degree of sex-linkage may be such that it could pass unnoticed unless a specific test is applied.

\section{DISCUSSION}

The present analysis of linkage studies with a mammalian species has not produced any novel results. Most of the general comments made earlier, apropos to the rabbit and rat material, are applicable to the deermouse. It only remains to emphasise the point that, with maximum likelihood scoring, no breeding data of reasonable consistency which could yield information on independent assortment need be wasted.

The proposal by McIntosh (1956a) that sequential analysis could be a useful tool in linkage investigation clearly deserves to be widely recognised. Sequential analysis would be particularly valuable in those situations where it is desirable to exclude a given level of linkage. In these cases, the objective could be achieved with the minimum of animals. Unfortunately, the general problem of circumventing the onset of diminishing returns with the preclusion of loose linkages has not been resolved. The only practical solution would be to make the collection of linkage data incidental to some other aspect of genetical research. The problem has been discussed in more detail by Robinson (1960).

\section{SUMMARY}

The published data on possible genetic linkage are reviewed and statistically analysed for independent assortment of the investigated gene loci. Estimates are derived for the combined data for $(a)$ the closest linkage compatible with the apparent random assortment or (b) the recombination fraction where random assortment is contradicted. Various aspects of the study of linkage in the deermouse are discussed. 


\section{REFERENCES}

BAILEY, N. T. J. 196I. Introduction to the theory of genetic linkage. Oxford University Press, London.

BARTO, E. 1942. Independent inheritance of certain genes in the deer-mouse. Peromyscus maniculatus. Papers Mich. Acad. Sci. Arts Lett., 27, 195-2 13.

BARTO, E. 1954. Spinner, an inherited type of abnormal behaviour in the beach mouse, Peromyscus polionotus. Contr. Lab. Vert. Biol., Univ. Mich., 66, 1-16.

BARTo, E. 1955. Boggler, an inherited abnormality of the deermouse (Peromyscus maniculatus) characterised by a tremor and a staggering gait. Contr. Lab. Vert. Biol., Univ. Mich., 7 I, I-26.

BARTo, e. 1956. Tests for independence of waltzer and $e p$ sonogenic convulsive from other genes in the deermouse. Contr. Lab. Vert. Biol., Univ. Mich., 74, I-16.

BLAIR, W. F. I944. Inheritance of the white-cheek character in mice of the genus Peromyscus. Contr. Lab. Vert. Biol,. Univ. Mich., 25, I-7.

BLAIR, W. F. 1947. An analysis of certain genetic variations in pelage color of the Chihuahua deer mouse (Peromyscus maniculatus blandus). Contr. Lab. Vert. Biol., Univ. Mich., 35, I-18.

GARTER, T. C., AND FALCONER, D. S. 1952. A review of independent segregation in the house mouse. 7. Genet., 5o, 399-413.

GLARK, F. H. 1936. Linkage of pink-eye and albinism in the deermouse. F. Hered., $27,256-260$.

CLARK, F. H. 1938. Inheritance and linkage relations of mutant characters in the deer-mouse. Contr. Lab. Vert. Biol., Univ. Mich., 7, I-1 I.

CRoss, J. C. 1931. A comparative study of the chromosomes of rodents. F. Morph., $52,373-401$.

CRoss, J. C. 1938. Chromosomes of the genus Peromyscus. Cytologia, 8, 408-419.

Egoscue, H. J. 1962. A new hairless mutation in deer mice. 7. Hered., 53, 192-194. EGOSGUE, H. J., AND DAY, B. N. 1958. Orange-tan-a recessive mutant in deer mice. 7. Hered., 49, 189-192.

Feldman, H. w. 1936. Piebald characters of the deer mouse. 7. Hered., 27, 300-304. FELDMAN, H. W. 1937. Segregation of mutant characters of deer mice. Amer. Nat., $7 r, 426-429$.

FISHER, R. A. 1946. A system of scoring linkage data with special reference to pied factors in mice. Amer. Nat., $80,568-578$.

haRPst, H. G., AND MARTin, A. 1950. Some chromosomes of rodents. Proc. Pa. Acad. Sci., 24, 36-39.

hUestis, R. R. 1940. Tests for linkage in Peromyscus. Genetics, 25, 121.

hUestis, R. R. 1942. Gene interaction in Peromyscus. Genetics, 27, 146-147.

HUestis, R. R. 1944. Tests for linkage of silver pelage and flexed-tail in Peromyscus. Yrb. Amer. Phil. Soc., (1953), 160-16I.

hUestrs, R. R. 1946. Linkage of flexed tail and albinism in Peromyscus. Genetics, $3 I, 219$.

HUESTIS, R. R., ANDERSON, R. S., AND MOTULSKY, A. G. 1956. Hereditary spherocytosis in Peromyscus. 7. Hered., 47, 225-228.

huestis, R. R., AND barto, E. 1934. Brown and silver deer mice. 7. Hered., 25, 219-223.

hUEstis, R. R., AND barto, E. 1936. Flex-tailed Peromyscus. 7. Hered., 27, 73-75.

hUESTIS, R. R., AND LiNDSTedT, G. 1946. Linkage relations of flexed-tail in Peromyscus. Amer. Nat., 8o, 85-9o.

hUestis, R. R., AND PIestrak, v. 1942. An aberrant ratio in Peromyscus. 7. Hered., $33,289-291$.

makino, s. 1953a. Chromosome numbers of some American rodents. Science, $I I 8,630$.

Makino, s. 1953b. Notes on the chromosomes of the Peromysci (RodentiaCricetidx). Experientia, 9, 214-216. 
matthey, R. 1952. Chromosomes de Muridæ. II. Experientia, 8, 389-390.

matthey, R. 1953. Les chromosomes des Muridx. Rev. Suisse Zool., 6o, 225-283. maintosh, w. в. 1956a. Linkage in Peromyscus and sequential tests for independent assortment. Contr. Lab. Vert. Biol., Univ. Mich., 73, I-27.

mantosh, w. в. 1956b. Whiteside, a new mutation in Peromyscus. 7. Hered., 47, 28-32.

MOREe, R. 1946. Genic sterility in interspecific hybrids of Peromyscus. Anat. Rec., 96,562 .

MOREE, R. 1948. The bearing of hybrid sterility on the genetic relationship of Peromyscus t. truei and P. n. nasutus. Genetics, 33, 621-622.

RAO, C. R. 1952. Advanced Statistical Methods in Biometrical Research. Chapman and Hall, London.

Robinson, R. 1956. A review of independent and linked segregation in the rabbit. 7. Genet., 54, 358-369.

Robinson, R. I960. A review of independent and linked segregation in the Norway rat. 7. Genet., 57, I 73-192.

sumner, F. B. 1922. Linkage in Peromyscus. Amer. Nat., 56, 412-417.

SUMNer, F. B. 1924. Hairless mice. F. Hered., 15, 475-481.

SUMNER, F. B., AND COLLINS, H. H. 1922. Further studies of color mutations in mice of the genus Peromyscus. 7. Exp. Zool., 36, 289-316.

TamsitT, J. R. 1960. The chromosomes of the Peromyscus truei group of white-footed mice. Texas 7. Sci., 12, 152-157. 